\title{
"Effects of inflation accounting on organizational decisions and financial performance in South African retail stores"
}

\begin{tabular}{|c|c|}
\hline AUTHORS & $\begin{array}{l}\text { Odunayo Olarewaju (D https://orcid.org/0000-0002-4366-040X } \\
\text { R https://publons.com/researcher/AAU-1024-2020 } \\
\text { Mzwandile Mbambo (D https://orcid.org/0000-0001-6408-6868 } \\
\text { Brian Ngiba (D https://orcid.org/0000-0001-5242-839X }\end{array}$ \\
\hline ARTICLE INFO & $\begin{array}{l}\text { Odunayo Olarewaju, Mzwandile Mbambo and Brian Ngiba (2020). Effects of } \\
\text { inflation accounting on organizational decisions and financial performance in } \\
\text { South African retail stores. Problems and Perspectives in Management, 18(4), } \\
\text { 85-95. doi:10.21511/ppm.18(4).2020.08 }\end{array}$ \\
\hline DOI & http://dx.doi.org/10.21511/ppm.18(4).2020.08 \\
\hline RELEASED ON & Monday, 16 November 2020 \\
\hline RECEIVED ON & Friday, 14 August 2020 \\
\hline ACCEPTED ON & Monday, 05 October 2020 \\
\hline LICENSE & $\begin{array}{l}(c) E_{\text {EY }} \\
\text { This work is licensed under a Creative Commons Attribution } 4.0 \text { International } \\
\text { License }\end{array}$ \\
\hline JOURNAL & "Problems and Perspectives in Management" \\
\hline ISSN PRINT & $1727-7051$ \\
\hline ISSN ONLINE & $1810-5467$ \\
\hline PUBLISHER & LLC "Consulting Publishing Company "Business Perspectives" \\
\hline FOUNDER & LLC "Consulting Publishing Company "Business Perspectives" \\
\hline
\end{tabular}

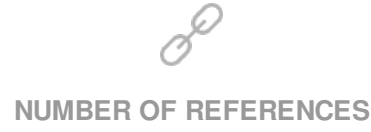

29

\section{NUMBER OF FIGURES}

3

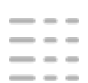

NUMBER OF TABLES

10

(C) The author(s) 2021. This publication is an open access article. 


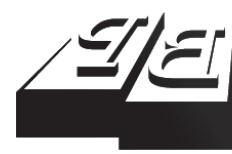

BUSINESS PERSPECTIVES

9

LLC "CPC "Business Perspectives" Hryhorii Skovoroda lane, 10, Sumy, 40022, Ukraine www.businessperspectives.org
Received on: $14^{\text {th }}$ of August, 2020 Accepted on: $5^{\text {th }}$ of October, 2020 Published on: $16^{\text {th }}$ of November, 2020

(C) Odunayo Olarewaju, Mzwandile Mbambo, Brian Ngiba, 2020

Odunayo Olarewaju, PhD., Senior Lecturer, Department of Management Accounting, Faculty of Accounting and Informatics, Durban University of Technology, South Africa.

(Corresponding author)

Mzwandile Mbambo, MAcc, Masters Student, Department of Financial Accounting, Faculty of Accounting and Informatics, Durban University of Technology, South Africa.

Brian Ngiba, MBA, Lecturer, Department of Financial Accounting, Faculty of Accounting and Informatics, Durban University of Technology, South Africa.

Odunayo Olarewaju (South Africa), Mzwandile Mbambo (South Africa), Brian Ngiba (South Africa)

\title{
EFFECTS OF INFLATION
} ACCOUNTING ON

\section{ORGANIZATIONAL DECISIONS AND FINANCIAL PERFORMANCE IN SOUTH AFRICAN RETAIL STORES}

\begin{abstract}
The inflation accounting technique allows a business to show or have a sensible picture of their gains due to present cost coordinates with present revenues. Thus, the effects of inflation accounting on organizational decisions and financial performance of Kwa-Zulu Natal retail stores were evaluated in this study. The study used a quantitative research method. A total of 161 completed questionnaires were received from respondents in the selected 20 listed stores in Kwa-Zulu Natal. Thus, the Exploratory Factor Analysis and linear regressions were employed in this study. The empirical study reveals how inflation accounting significantly impacts organizational decisions and financial performance of the retail business with such coefficients $(\mathrm{F}(1,159)=$ $49.269, \mathrm{p}<.0005 ; \mathrm{F}(1,159)=28.959, \mathrm{p}<.0005)$. The findings of this study highlighted positive relationships between the variables that were used. Thus, the study recommends that retail stores always consider inflation changes and apply inflation accounting techniques to make adjustments to produce more accurate results in their financial statements. Heated discussions now surround the basis of financial performance measurement via historical cost accounting. This influences their decision making and financial performance positively.
\end{abstract}

\section{Keywords}

JEL Classification

\section{INTRODUCTION}

Inflation accounting is better known as 'price level accounting'. It is a special accounting technique used to adjust the financial statements. The company's financial statements are adjusted when there is a material amount of price inflation, causing historical Information on the financial statements to be irrelevant or less useful. A lot of retail stores are dependent on financial statements that are based on historical information. Information becomes less useful to the business and the users of financial statements because inflation has not been considered. Using historical costs on financial statements is unsuitable as figures become distorted and less reliable. Also, amounts are overstated on financial statements. The overstatement causes a false comparison, and a reflection of the business's weak point becomes difficult to pin out. It cannot be denied that a historical cost basis is good when one needs to measure assets. However, problems are encountered when prices shift over time between the dates when assets were bought and the current date. In this case, using historical costs will not be relevant if the main reason to take a measurement is to show the most recent economic gain reflected by the financial performance. 
Reliability is essential in financial statements so that the information presented is useful. Reliable information comes in handy when business decisions have to be made. Moreover, if proper business decisions are made, there will be an improvement in financial performance. With that being said, financial statements would be more practical to the retail stores. An economic entity prefers income calculated correctly, considering the effects of inflation to ascertain the real purchasing power of such profit. When financial statements are measured and presented on a historical cost basis, they ignore the effects of changes in price levels of assets and transactions if inflation accounting is used as inflation is a continuous problem that influences the accounting system. Retail stores must use inflation accounting as it reflects the true value of the business. Nearly the same is that it reviews any suspicious amounts, which may be performed on a historical cost basis that may show big amounts of tax and profits. The business will always be at risk if correct methods are not applied because retailers deem inflation accounting as too complex to understand. Therefore, retailers must use inflation accounting to prevent financial statements from being reported incorrectly, especially when inflation and interest rates shift drastically.

This study highlights the value and encourages retail stores to use inflation accounting. This paper aims to fill the misinformation gap that the retail stores have and direct them to improve their financial wellbeing. Accordingly, this paper acts as a tool to analyze and further elucidate the subject matter and add to the existing knowledge and literature.

Since inflation is a chronic case, it should be accounted for by companies. Thus, the companies can evaluate and adjust financial statements more realistically to overcome the changes made by inflation developments. It is worthy to note that accounting methods estimates and interpretations of financial statements are recurrent accounting issues. Annual reports must be accurate to make correct organizational decisions, improve business quality and performance. This study highlights the appropriate measures that should be taken during periods of high inflation and prepares companies to use methods that should be applied in the case of high inflation developments in the future.

\section{LITERATURE REVIEW}

\subsection{Empirical review on the consideration of inflation in organizational decisions for retail stores}

Phiri (2017) states that his research was conducted to understand more about how people would react to inflation and expectations, based on the amount of knowledge they have. Also, individuals failed to understand the relationship between inflation and prices and were unaware of past and future inflation measures. This could mean that the respondents have a limited understanding of the whole inflation concept and therefore fail to know food prices and inflation. Moreover, managing inflation expectations is very important because it is the core aspect of monetary policy. According to Hillier et al. (2016), secretive cultures prevent users from seeing the upward movements of inflation in financial statements because it is easy to conceal earnings and asset values. Businesses engage in these concealments to avoid the responsibility of accounting to external investors. Hiller et al. (2016) mention that the valuation impact of International Financial Reporting Standards (IFRS) on capital markets is now a foundational international matter in question. With over 120 countries that are developed or underdeveloped, they should be adopting IFRS. Financial statements' effectiveness for economic decisions depends entirely on the accounting principles used in preparing data and its validity.

Mikolajun and Lodge (2016) argue whether globalization has rendered national inflation less responsive to domestic capacity restrictions. A sudden expansion in demand for goods would translate into higher imports rather than into prices or foreign competition curbs wage/price increases. Wage or price increases mostly affect industries 
that are open to global competition. A huge rise in costs tends to lower the sensitivity of wages to productivity increases. Tawiah et al. (2015) add that the basic principle of credit transactions is ignored by inflation accounting. It directly calculates monetary gain or loss on the credit price, expecting that credit price and market price are the same. "Inflation accounting may argue that this price difference is just to discourage credit sales or purchases, or to compensate for the risk of default but not to take care of inflation" (Tawiah et al., 2015).

According to Madito and Odhiambo (2018), money supply expansion is expressed by upward pressure being applied on prices by changes in structural and cost factors. Secondly, an analysis of the three main structural causes of inflation shows that underlying factors yield the basis against which the inflation process occurs. It also explicates the endangerment of the economy regarding inflation. However, the underlying factors cannot provide an easily understandable explanation of what good could come out of the rate of inflation or the reasoning behind the question of why it descends or gains momentum in different cases. These remain crucial factors in the determination of inflation. Lastly, it may be argued that there is an existence of imported inflation, drawn from the price of exports that other African countries encounter because of the South African inflation influence. Policy rates below average have better chances of leveling up risks that will further increase financial imbalances, while the relationship between economic growth and inflation is known to have an upswing in the supply of money. Therefore, inflation is created, which leads to capital accumulation growth that creates an economic increase effect (Norges Bank, 2014). Pierdzioch et al. (2014) state that South Africa's economy and the financial sector have a power and influence over other African countries. South Africa's economic links are also boosted by influential, prominent market countries such as China and India. Just because inflation has been quite moderate compared to previous years, investors should not overlook and be unappreciative of this matter. Investors must act with reasonable care in consideration of the future by maintaining their equity levels so that they are shielded against the erosive effects of inflation.

\subsection{Empirical review on the effects of inflation accounting on financial performance}

Inflation is a continuous problem that affects the accounting system in many countries, causing structural economic issues. These problems will always carry a risk of economic instability until resolved. The best way to correct such problems is to adjust financial statements, with inflation accounting being necessary to achieve this correction. Hyperinflation (high inflation) inhibits financial statements, drawn upon historical cost requirements, from creating financial Information that would be comparable and comprehensible for the business. Rapu et al. (2016) mention that high inflation is detrimental to an economy for several reasons: it distorts prices; depletes savings; discourages investment; leads to and/or fuels capital flight; hinders growth; economic planning becomes difficult; and exacerbates possible social and political disturbances. A slight increase in inflation can significantly affect a business's operations and financial position results.

Accounting bodies are working on various methods to address inflation effects on financial accounting (Tawiah et al., 2015). Inflation accounting is very important for the business because, on many occasions, income taxes owed and reported earnings are overstated when the asset figures decrease. This is caused by the understatement of depreciation based on historical cost (Mishra, 2018). Furthermore, the net income is affected in various manners based on the adoption of cost flow techniques in inventory valuation and interest expense in company profits. A downward movement is expected in taxes owed as the debt value is weakened by inflation. This clearly explains the understatement of earnings and the exaggeration of past interest expenses. South African Reserve Bank (2019) states that investors are guided by the business's financial performance to make correct investment decisions. Therefore, the financial statements should not be misleading. Historical cost accounting is increasingly becoming a dissatisfactory method of preparing financial statements. A room should be made to consider using a different technique, like inflation accounting. The dispute behind historical cost accounting is the assumption of inflation rates being non-exist- 


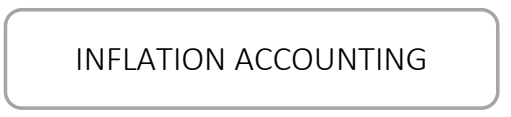

Independent variable

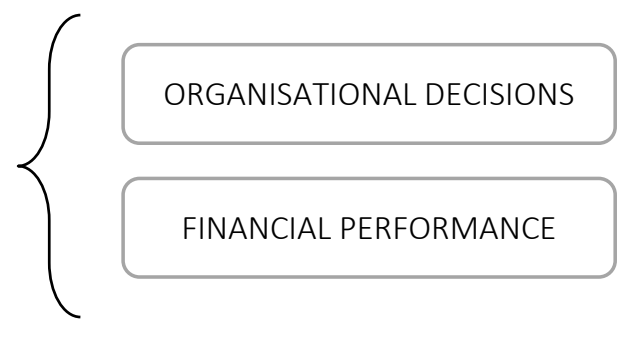

Dependent variable

Figure 1. Conceptual framework

ent or being brushed aside, which causes a conclusive decrease in the company's value and the under-valuation of aged assets (Tawiah et al., 2015).

The research hypotheses:

$H_{01}:$ Inflation accounting does not affect organizational decisions of KZN retail stores.

$H_{02}:$ Inflation accounting does not affect the financial performance of KZN retail stores.

\subsection{Theoretical framework}

This study will be hinged on the current purchasing power accounting theory because it assists in reporting equal purchasing power units. It further uses general and consumer price indexes to restate units done on historical costs, without forgetting non-monetary items that need to be adjusted. Asuquo et al. (2017) agree that when an adjustment of the historical cost of an asset is made to the current cost, the asset's spot-on prices will be revealed. Hence, it would be wise to use the General Price Index (GPI) as this clearly shows the movements in price levels in both statements of profit or loss and other comprehensive income and the statement of financial position. General and consumer prices are examples of indexes/indices used to restate units and are done on previous costs, taking note of non-monetary items that need to be adjusted (Asuquo et al., 2017).

\subsection{Conceptual framework}

Figure 1 depicts the relationship between inflation accounting (independent variable) on organisa- tional decisions and financial performance (dependent variables) of the retail stores.

\subsection{Methodology}

A quantitative research design that falls under the positivist paradigm was used. The quantitative aspect of the research was based on the data gathered from the five-point Likert scale questionnaire. Retail stores in the Kwa-Zulu Natal (KZN) province have been selected to analyze its organizational decisions and financial performance. There is an approximation of 30 retail stores listed on the Johannesburg Stock Exchange (JSE) in South Africa ${ }^{1}$, but only a sample of 20 out of 30 listed JSE retail stores was visited because other listed JSE stores are inaccessible in the KZN area. Only those that are easily accessible are selected.

A census sampling technique was used to select all the listed retail stores in KZN province. A total of 200 questionnaires have been administered to respondents from different branches in each of the 20 JSE-listed KZN retail stores. Specifically, 5 questionnaires were administered to each visited store. The respondents were financial managers, bookkeepers, accountants, accounts clerks, and junior accountants to measure the study's objective. The researcher received 161 completed questionnaires from respondents. This is very good because it implies that the response rate is $80.5 \%$, although a small portion of questionnaires was partially complete due to time limitations that the respondents had. On the other hand, 39 (19.5\%) of the questionnaires were returned by the participants unanswered. 


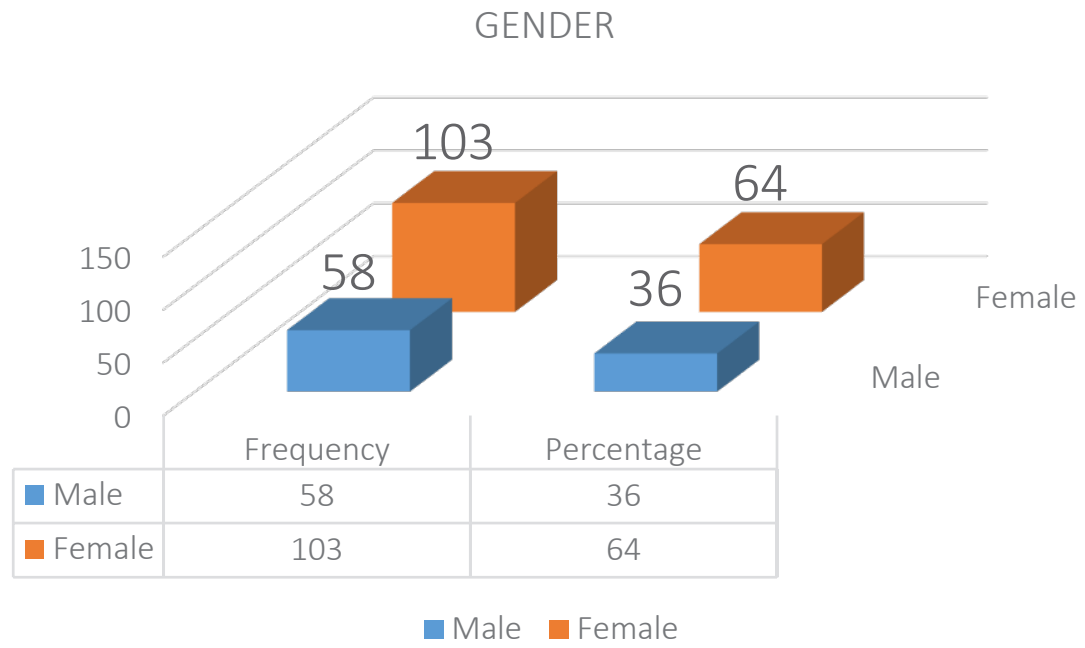

Figure 2. Gender of participants

The Statistical Package for the Social Sciences (SPSS) was used for the data analysis through Exploratory Factor Analysis (EFA) to determine the factor structures of items employed to measure each of the constructs measured in this study. Then, the Cronbach's alpha test was conducted to determine the reliability of each construct. The Kaiser-Meyer-Olkin (KMO) is employed to establish the adequacy of the sample size for this study. Hayakawa (2020) stated that the KMO test is used to measure the suitability of data for factor analysis. Lastly, linear regression was done to determine the influence of the independent variables against the dependent variables.

\section{RESULTS AND DISCUSSION OF DATA ANALYSIS}

\subsection{Demographic information analysis}

The survey questionnaire's demographic section elicited categories of demographic data from the survey respondents, which included gender and work designation. The following bar chart in Figures 2 and 3 depict the respondents' demographic details.

\subsubsection{Gender}

As shown in Figure 2, 58 of the total respondents (representing 36\%) were male, while 103 (representing 64\% of the total respondents) were female. Based on the outcome of the statistical analysis, a majority of the study participants were female.

\subsection{Work designation}

The 3D pie chart in Figure 3 shows the work designation of respondents. Financial managers were $40 \%$; bookkeepers $19 \%$; accountants $27 \%$; junior accountants $13 \%$, and accounts clerks $1 \%$, respectively. The results show that the highest responses were from the financial managers (40.4\%) because they have the biggest impact on the company and make decisions within its operations' total context.

\subsection{Exploratory Factor Analysis test (EFA)}

An Exploratory Factor Analysis (EFA) was conducted to determine the factor structures of items employed to measure each of the constructs evaluated in this study. Furthermore, the EFA was used to minimize the dimensions and hike of any missing data. The EFA has been very useful to guarantee the process of linearity. The Principal Component Analysis (PCA) has been used to establish which factors need to be extracted. Jolliffe and Cadima (2016) describe PCA as a technique used to cut down the dimensionality of datasets, increase interpretation, and lower the loss of information. The Kaiser-Meyer-Olkin (KMO) test was employed 


\section{WORK DESIGNATION}

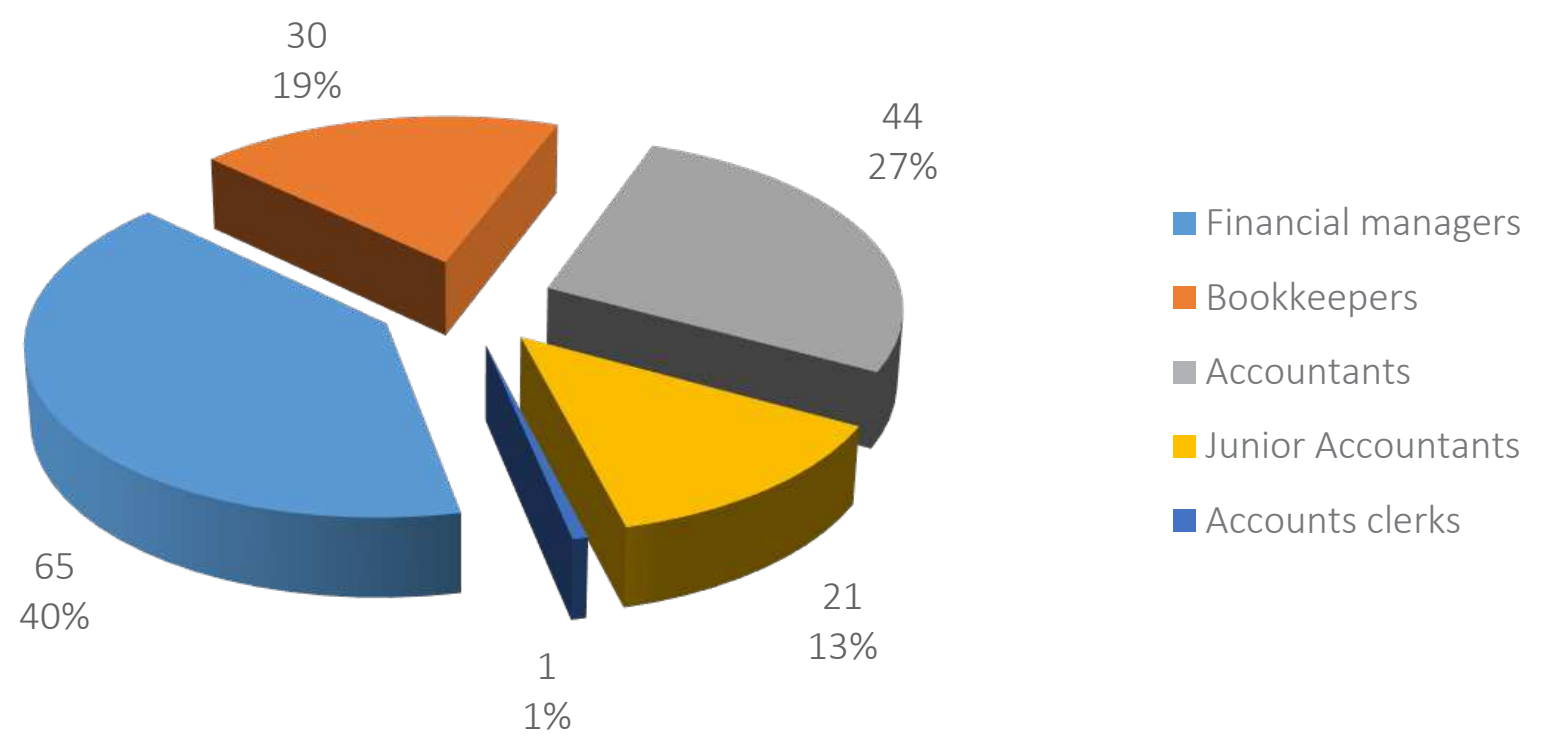

Figure 3. Work designation

to establish the sample size's adequacy for this study. The KMO test was used to measure the suitability of data for factor analysis. According to Hayakawa (2020), the KMO entry level is from the value of 0.5 , but 0.6 is mediocre, while 0.7 and 0.8 is good, 0.9 great, and above 0.9 is considered excellent. In conducting the EFA, items with a factor loading of 0.5 and above were retained, while items with loadings of below 0.5 and items that cross-loaded were dropped in the final analysis. The reason for dropping loadings below 0.5 is to avoid feedback or questions that do not influence the variable as some factors are not strong enough.

Table 1. Sampling adequacy

\begin{tabular}{c:cc}
\hline \multicolumn{2}{c}{ Kaiser-Meyer-Olkin measure of sampling adequacy } \\
\hline \multirow{3}{*}{ Bartlett's test of sphericity } & Approx. Chi-square & .756 \\
\cline { 2 - 3 } & Df & 12230.236 \\
& Sig. & .000 \\
\hline
\end{tabular}

As illustrated in Table 1, the KMO for this study is 0.756 , which is of the sample's adequacy. The Bartlett's test of sphericity is significant at $p<$ 0.001 , which justified why the EFA was performed. Tables 2-8 showcase the factor loadings of the items measuring each of the constructs in this study.
Table 2. Factor: Organizational Decision (OD)

\begin{tabular}{l|c}
\hline \multicolumn{1}{c}{ OD items extracted } & Factor loadings \\
\hline OD 1 & .724 \\
\hline OD 2 & .707 \\
\hline OD 3 & .650 \\
\hline OD 4 & .503 \\
\hline OD 5 & .637 \\
\hline OD 8 & .613 \\
\hline OD 9 & .599 \\
\hline OD 11 & .611 \\
\hline OD 12 & .615 \\
\hline OD 13 & .688 \\
\hline OD 14 & .586 \\
\hline OD 15 & .505 \\
\hline Cronbach's alpha & No. of items \\
\hline 891 & 12 \\
\hline
\end{tabular}

Table 2 illustrates the factor loadings of the items retained for organizational decisions. Of the 15 items used to measure the constructs, only three items below the threshold of 0.5 were dropped, while the items retained after conducting the EFA include: OD 1 - My organizational decisions include a careful scrutiny of every possible alternative $(\boldsymbol{\sigma}=0.724)$, followed by OD $2-\mathrm{My}$ organizational decisions include an appraisal of every possible alternative $(\boldsymbol{\sigma}=0.707)$, OD $3-$ I am aware that decision-making in management is an essential skill required for businesses as it determines the success of the retail store I work for $(\boldsymbol{\sigma}=0.650)$, OD $4-$ The person responsible 
becomes accountable for bad decisions made for the retail store $(\boldsymbol{\sigma}=0.503)$, OD 5 - Inflation alters figures in the company's financial statement even when the rate is low; this change affects the business operations $(\boldsymbol{\sigma}=0.637)$, OD 8 - Having enough cost information plays a big role in making decisions for my organization $(\boldsymbol{\sigma}=0.613)$, OD 9 - I have a good understanding of environmental factors (technological, economical etc.) for the retail store I work for $(\boldsymbol{\sigma}=0.599)$, OD $11-$ It's always wise to have a retail strategy in order to meet the store objectives $(\boldsymbol{\sigma}=0.611)$, OD 12 - The store I work for has management with good leadership skills on employees, communication and customer service skills $(\boldsymbol{\sigma}=0.615)$, OD 13 Timing of decisions made is very important in order to view any conditions which may exist at a particular time $(\sigma=0.688)$, OD 14 - I'm aware that employee participation in decision-making makes the execution easier for the retail store ( $\boldsymbol{\sigma}$ $=0.586)$ and OD 15 - Decision-making is negatively affected when financial data is outdated $(\sigma=0.505)$, respectively. The 12 items retained for measuring this construct (organizational decision) have good reliability with a Cronbach's alpha of 0.891 . Good reliability indicates the internal consistency of the construct measures (Sekaran \& Bougie, 2016; Wilson, 2014).

Table 3. Factor: Usefulness of Inflation Accounting Technique (UIA)

\begin{tabular}{l|c}
\hline \multicolumn{1}{c|}{ UIA items extracted } & Factor loadings \\
\hline UIA 1 & .750 \\
UIA 2 & .777 \\
\hline UIA3 & .753 \\
\hline UIA4 & .694 \\
\hline UIA 5 & .806 \\
\hline Cronbach's alpha & No. of items \\
\hline .939 & 5 \\
\hline
\end{tabular}

Table 3 illustrates the factor loadings of the items retained for the usefulness of the inflation accounting technique. Of the 5 items used to measure the constructs, none of the items was dropped as no items were below the 0.5 threshold. The items retained after conducting the EFA include: UIA 1 - Ability to spot misleading deeds $(\boldsymbol{\sigma}=0.750)$, followed by UIA 2 - The retail store would be able to pick up wrong matching concepts $(\boldsymbol{\sigma}=0.777)$, UIA 3 - Allows a fair balancing statement of financial position $(\boldsymbol{\sigma}=0.753)$, UIA
4 - safety of owners' equity $(\boldsymbol{\sigma}=0.694)$ and UIA 5 - reasonable comparison of profitability $(\boldsymbol{\sigma}=$ 0.806) accordingly. Cronbach's alpha for the 5 items retained is 0.939 .

Table 4. Factor: Inflation Accounting Technique (IAT)

\begin{tabular}{l|c}
\hline \multicolumn{1}{c|}{ IAT items extracted } & Factor loadings \\
\hline IAT 1 & .783 \\
\hline IAT 2 & .764 \\
\hline IAT 3 & .684 \\
\hline IAT 4 & .653 \\
\hline IAT 5 & .629 \\
\hline Cronbach's alpha & No. of items \\
\hline 844 & 5 \\
\hline
\end{tabular}

Table 4 illustrates the factor loadings of the items retained for the inflation accounting technique. Of the 5 items used to measure the constructs, none of the items were dropped as there was no item below the 0.5 threshold. The items retained after conducting the EFA include IAT 1 - It has a lot of complex calculations $(\boldsymbol{\sigma}=0.783)$, followed by IAT 2 - Good in theory not practically $(\boldsymbol{\sigma}=0.764)$, IAT 3 - Constant adjustments need to be made ( $\boldsymbol{\sigma}$ $=0.684$ ), IAT $4-$ Not everyone would be able to use this technique $(\boldsymbol{\sigma}=0.653)$ plus IAT 5 - It is very costly $(\boldsymbol{\sigma}=0.629)$. Cronbach's alpha for the 5 items retained is 0.844 .

Table 5. Factor: Performance Monitor (PM)

\begin{tabular}{l|c}
\hline \multicolumn{1}{c|}{ PM items extracted } & Factor loadings \\
\hline PM 1 & .750 \\
\hline PM 2 & .557 \\
\hline PM 3 & .600 \\
\hline PM 4 & .609 \\
\hline Cronbach's alpha & No. of items \\
\hline 849 & 4 \\
\hline
\end{tabular}

Table 5 illustrates the factor loadings of the items retained for performance monitor. Of the 5 items used to measure the constructs, only one item below the threshold of 0.5 was dropped. The items retained after conducting the EFA include PM 1 - By conducting a competitor analysis $(\boldsymbol{\sigma}=0.750)$ is most likely to be used by the store to monitor its performance, followed by PM 2 - By assessing the store's efficiency $(\boldsymbol{\sigma}=0.557)$, PM 3 - By conducting a customer analysis $\boldsymbol{\sigma}=(0.600)$ and PM 4 - By conducting market analysis $(\boldsymbol{\sigma}=0.609)$. Cronbach's alpha for the 4 items retained is 0.849 . 
Table 6. Factor: Standpoints Considered when Introducing Performance Measurement (SC)

\begin{tabular}{l|c}
\hline \multicolumn{1}{c|}{ SC items extracted } & Factor loadings \\
\hline SC 1 & .598 \\
SC 2 & .682 \\
\hline SC 3 & .687 \\
SC 4 & .770 \\
\hline SC 5 & .682 \\
\hline Cronbach's alpha & No. of items \\
\hline .830 & 5 \\
\hline
\end{tabular}

Table 6 shows the factor loadings of the items retained for standpoints considered when introducing performance measurement. Of the 5 items used to measure the constructs, none of the items were dropped as there was no item below the 0.5 threshold. The items retained after conducting the EFA include: SC 1 - Financial $(\boldsymbol{\sigma}=0.598)$, as well as SC 2 - Shareholders' $(\boldsymbol{\sigma}=0.682)$, SC 3 - Customers' $(\boldsymbol{\sigma}=0.687)$, SC $4-$ Employees' $(\boldsymbol{\sigma}=0.770)$ and SC 5 - Retail stores' internal business processes $(\boldsymbol{\sigma}$ $=0.682$ ), respectively. Cronbach's alpha for the 5 items retained is 0.830 .

Table 7. Factor: Non-Financial Performance Measures (NFP)

\begin{tabular}{l|c}
\hline \multicolumn{1}{c|}{ NFP items extracted } & Factor loadings \\
\hline NFP 1 & .740 \\
NFP 2 & .688 \\
\hline NFP 3 & .723 \\
\hline NFP 4 & .744 \\
NFP 5 & .720 \\
\hline Cronbach's alpha & No. of items \\
\hline .924 & 5 \\
\hline
\end{tabular}

Table 7 shows the factor loadings of the items retained for non-financial performance measures. Of the 5 items used to measure the constructs, none of the items were dropped as there was no item below the 0.5 threshold. The items retained after conducting the EFA include NFP 1 - Encouraging development $(\boldsymbol{\sigma}=0.740)$ is indeed an important non-financial performance measure for the retail store, followed by NFP 2 - Creating a positive work environment $(\boldsymbol{\sigma}=0.688)$, NFP 3 - Retaining and attracting high-value customers $(\boldsymbol{\sigma}=0.723)$, NFP 4 - Store I work for to become a leading retail store $(\boldsymbol{\sigma}=0.744)$ and NFP 5 - Facilitating the integration of the retail store's plans with financial plans $(\boldsymbol{\sigma}=0.720)$. Cronbach's alpha for the 5 items retained is 0.924 .
Table 8. Factor: Employee Performance Review (EPR)

\begin{tabular}{l|c}
\hline \multicolumn{1}{c|}{ EPR items extracted } & Factor loadings \\
\hline EPR 1 & .579 \\
\hline EPR 4 & .688 \\
\hline EPR 5 & .663 \\
\hline EPR 6 & .707 \\
\hline EPR 7 & .656 \\
\hline Cronbach's alpha & No. of items \\
\hline 903 & 5 \\
\hline
\end{tabular}

Table 8 represents the factor loadings of the items retained for employee performance review. Of the 7 items used to measure the constructs, only two items below the threshold of 0.5 were dropped. The items retained after conducting the EFA include: ERP 1 - Able to meet deadlines $(\boldsymbol{\sigma}=0.579)$, followed by ERP 4 - Have good attendance $(\boldsymbol{\sigma}=$ $0.688)$, ERP 5 - Produce quality and accurate work $(\boldsymbol{\sigma}=0.663)$, ERP 6 - Have good communication skills $(\boldsymbol{\sigma}=0.707)$ and ERP 7 - Collaboration skills and teamwork $(\boldsymbol{\sigma}=0.656)$. Cronbach's alpha for the 5 items retained is 0.903 .

Factors shown in each table portray positive results for every factor that was loaded. This is all subject to the feedback obtained from respondents, even though there is a possibility to obtain different responses from different industries. Besides, it is incorrigible that all the factor items used in this study are good, as Cronbach's alpha exceeds 0.8 (Hayakawa, 2020).

\subsection{Regression analysis to address the influence of inflation on organizational decisions}

The outcomes of the regression analysis are summarized in Table 9. The $\mathrm{R}^{2}$ value of 0.237 shows that inflation accounts for $23.7 \%$ of the variance in organizational decisions, and there is a significant linear relationship between inflation and organizational decisions, $\mathrm{F}(1,159)=49.269, p<.0005$. The independent variable, inflation, is a significant predictor of organizational decisions, $B=0.852$, $p<0.0005$. Based on this outcome, the null research hypothesis one was rejected, which means that inflation affects organizational decisions. Consistent with this finding is the study conducted by Naudon and Perez (2017), where they found that inflation influences organizational decisions. 
Table 9. Influence of inflation on organizational decisions

\begin{tabular}{l|c|c|c|c|c|c|c|c}
\hline $\begin{array}{c}\text { Variables in } \\
\text { the equation }\end{array}$ & B & Beta & $\mathbf{T}$ & $\boldsymbol{p}$-value & $\mathbf{R}^{\mathbf{2}}$ & $\mathbf{F}$ & Df & $\boldsymbol{p}$-value \\
\hline Constant & 32.009 & & 13.566 & $<.0005$ & .237 & 49.269 & $1 ; 159$ & $<.0005$ \\
\hline Inflation & .852 & .486 & 7.019 & $<.0005$ & & \\
\hline
\end{tabular}

Note: Independent Variable - Inflation accounting; Dependent Variable - Financial performance

Table 10. Effects of inflation accounting on financial performance

\begin{tabular}{l|c|c|c|c|c|c|c|c}
\hline $\begin{array}{c}\text { Variables } \\
\text { in the equation }\end{array}$ & B & Beta & $\mathbf{T}$ & $p$-value & $\mathbf{R}^{2}$ & $\mathbf{F}$ & Df & $p$-value \\
\hline $\begin{array}{l}\text { Constant } \\
\text { Inflation }\end{array}$ & 21.337 & & 10.640 & $<.0005$ & & & & \\
accounting & .555 & .393 & 5.381 & $<.0005$ & .154 & 28.959 & $1 ; 159$ & $<.0005$ \\
\hline
\end{tabular}

Note: Independent Variable - Inflation accounting; Dependent Variable - Financial performance

Since the results certify that inflation affects organizational decisions, this brings an alert to retail stores. McMahon (2017) states that people's opinions are not enough to make correct business decisions for the retail store. Although many factors can influence the organizational decision, inflation poses a threat to decisions. Consequently, retail stores make bad business decisions because inflation was not considered. Above all, these findings are an indication of the influence that cannot be avoided by retailers.

\subsection{Regression analysis to address the effects of inflation accounting on performance}

The results of the regression analysis are summarized in Table 10. The $\mathrm{R}^{2}$ value of 0.154 shows that inflation accounting accounts for $15.4 \%$ of the variance in performance, and there is a significant linear relationship between inflation accounting and financial performance, $\mathrm{F}(1,159)$ $=28.959, p<.0005$. The independent variable, inflation accounting, is a significant predictor of financial performance, $B=0.555, p<0.0005$. Based on this outcome, the null research hypothesis two was rejected; hence, inflation accounting affects KZN retail stores' financial performance. The study findings agree with Ebiaghan (2019) who also established the significant effects of inflation accounting on financial performance. This misinformation causes retail stores to disregard using this accounting technique. While, Asuquo et al. (2017) highlight that inflation accounting is very effective in the business's financial performance. Thereupon, the findings verify that inflation accounting affects the financial performance of the retail stores.

\section{CONCLUSION}

This paper intended to examine whether inflation accounting influences organizational decisions and financial performance. Findings obtained from this research certified that inflation does affect organizational decisions and financial performance. This has been confirmed by findings from previous studies that agreed to this study (Naudon \& Perez, 2017; Ebiaghan, 2019). Thus, financial statements must be correct to have a clear analysis of the company's financial well-being. If businesses use inflation accounting techniques, their financial statements stand to have better results than other accounting techniques that do not adjust inflation on financial statements. Even though retailers are still dependent on a historical cost basis, it is unquestionable that this method has more disadvantages than inflation accounting. The historical cost basis is not a good method to be used in the financial statements as it overlooks the importance of taking note of inflation. Using the correct method of accounting is very crucial for decision-making purposes of the business. Decisions made affect the direction of business performance. Therefore, users cannot rely on financial statements prepared on historic costs when business decisions have to be made, e.g., investments. The research also acknowledged the fact that retail 
stores divert from using inflation accounting because of its complexity. Furthermore, respondents some stores were not familiar with inflation accounting. Not being conversant could mean that there are no methods applied to adjust inflation since respondents are interactive in the accounting department. Thus, financial statements are affected as there is no indication of true amounts recorded, especially when the inflation accounting technique is not employed. Consequently, businesses must adjust their financial statements to present accurate results. In so doing, companies are not being misled by unadjusted figures due to inflation. Also, it encourages good decision-making for the business. In the end, the information contained in the financial statements should be valid, accurate, and reliable.

\section{RECOMMENDATIONS}

Based on the findings of the study, there are recommended the retail stores should consider carrying out different methods of encouraging staff to perform better. Have more training, have some staff work from different departments and have rewards for the best performers. This will increase their motivation, skills, and input towards the store. Furthermore, it will boost the performance of staff and the stores' financial performance. Retail stores should be aware of inflation changes and apply inflation accounting techniques to make adjustments to produce more accurate results in their financial statements. By doing so, it ensures that the business is a going concern. The study also recommends that policymakers make better policies to stabilize the rate of inflation so that it does not have a major effect on the retail stores' financial performance.

Financial statements prepared on a historical basis and based on current cost should be made available to the store for comparison. This will enable the store to see the true worth of business so that investors can make proper decisions based on accurate results.

\section{AUTHOR CONTRIBUTIONS}

Conceptualization: Odunayo Olarewaju, Brian Ngiba.

Data curation: Odunayo Olarewaju, Mzwadile Mbambo.

Investigation: Odunayo Olarewaju, Mzwadile Mbambo, Brian Ngiba.

Methodology: Mzwadile Mbambo, Brian Ngiba.

Supervision: Odunayo Olarewaju, Brian Ngiba.

Writing - original draft: Mzwadile Mbambo, Brian Ngiba.

Writing - review \& editing: Odunayo Olarewaju, Brian Ngiba.

\section{REFERENCES}

1. Amaefule, L. I., Okoye, E. I., Kalu, E. O., \& Nwosu, S. U. (2018). Fair Value Measurement versus Historical Cost Accounting: A Comparative Effect on Firms' Performance in Nigeria. Research Journal of Finance and Accounting, 9(10), 165-175. Retrieved from https://www.iiste.org/Journals/index. php/RJFA/article/view/42664/43983

2. Asuquo, A. I., Adenike, F. A., Ogar, O. L., Ebahi, A. O., \& Okon, G. E. (2017). Effect of inflation accounting on business measurement of quoted manufacturing companies in

Nigeria. Imperial Journal of Interdisciplinary Research (IJIR), 3(1), 1886-1894. Retrieved from http://www.onlinejournal.in/IJIRV3I1/337.pdf

3. Brou, F. B., \& Kruger, T. M. (2016). Continental and national differences in the financial ratios of investment banking companies: an application of the Altman Z model. Journal of Accounting and Finance, 16(3), 37-49. Retrieved from https:// articlegateway.com/index.php/JAF/ article/view/1018
4. Bryman, A., \& Bell, E. (2015).

Business research methods (4th ed.). Retrieved from https://books.google. co.za/books?hl=en\&lr=\&id=17u6B wAAQBAJ\&oi=fnd\&pg=PP1\&dq=r eliability+and+validity\&ots=AwMp z6IVKn\&sig=g9c0ovp_tth0IvqT9x OVobuDYo\#v=onepage $\& \mathrm{q}=$ reliabili ty\%20and\%20validity\&f=false

5. De Boeck, P., Cho, S., \& Wilson, M. (2016). Explanatory Item Response Models. In A. A. Rupp \& J. P. Leighton (Eds.), The Wiley handbook of cognition and assessment: 
Frameworks, methodologies and applications. https://doi. org/10.1002/9781118956588.ch11

6. Ebiaghan, O. F. (2019). A Comparative Analysis of Inflation-Adjusted and Historical Cost Accounting Information: Implications for the Value Relevance of Corporate Reports. Trends Economics and Management, 13(33), 35-50. http://dx.doi. org/10.13164/trends.2019.33.35

7. Etikan, l., Musa, S. A., \& Alkassim, R. S. (2016). Comparisons of convenience sampling and purposive sampling. American Journal of Theoretical and Applied Statistics, 5(1), 1-4. http://dx.doi. org/10.11648/j.ajtas.20160501.11

8. Hashim, H. T., Jumaah, A. A., \& Jasim, M. A. (2019). Impact of Fair Value Accounting, Historical Cost Accounting and Subprime Mortgages on the Global Financial Crisis. Transylvanian Review of Administrative Sciences.

9. Hayakawa, K. (2020). The weakinstruments problem in factor models. Behaviormetrika, 47, 123157. https://doi.org/10.1007/S41237019-00097-1

10. Hillier, D., Hodgson, A., \& Ngole, S. (2016). IFRS and Secrecy: Assessing Accounting Value Relevance across Africa. Journal of International Financial Management and Accounting, 27(3), 237-268. http:// dx.doi.org/10.1111/jifm.12043

11. Javed, R. (2019). Merits and Demerits of Inflation Accounting PlayAccounting. Retrieved from https://www.playaccounting.com/ exp-ca/inflation-accounting/ merits-and-demerits-of-inflationaccounting/

12. Jolliffe, I. J., \& Cadima, J. (2016) Principal component analysis: a review and recent developments. Philosophical Transactions A, 374, 1-16. https://doi.org/10.1098/ rsta.2015.0202

13. Khandan, A., \& Hosseini, S. M. (2016). Determinants of Inflation: A Case Study of Iran. Applied Economics and Finance, 3(4), 95102. http://dx.doi.org/10.11114/aef. v3i4.1760

14. Kumar, R. (2014). Research methodology: a step-by-step guide for beginners (4th ed.). London: Sage Publications Ltd.

15. Madito, O., \& Odhiambo, N. M. (2018). The main determinants of inflation in south Africa: an empirical investigation. Organizations and Markets in Emerging Economies, 9(2), 212232. https://doi.org/10.15388/ omee.2018.10.00011

16. McMahon, T. (2017). Effects of inflation on businesses. InflationData. Retrieved from https://inflationdata.com/articles/2017/06/07/effects-of-inflationon-businesses/

17. Mikolajun, I., \& Lodge, D. (2016). Advanced economy inflation: The role of global factors (ECB Working Paper No. 1948). European Central Bank. http://dx.doi. org/10.2866/747723

18. Mishra, S. (2018). 4 methods of price level accounting: Techniques. Financial analysis. Retrieved from https://www.yourarticlelibrary. com/accounting/price-levelaccounting/4-methods-of-pricelevel-accounting-with-calculationsfinancial-analysis/67498

19. Naudon, A., \& Perez, A. (2017). An overview of inflation-targeting frameworks: institutional arrangements, decision-making and the communication of monetary policy (Working Papers of the Central Bank of Chile No. 811). Banco Central de Chile. Retrieved from https://si2.bcentral.cl/public/ pdf/documentos-trabajo/pdf/ dtbc811.pdf

20. Norges Bank. (2014). Monetary Policy Report with Financial Stability Assessment. Retrieved from https://static.norges-bank. no/contentassets/53f33130a 4684bfc9187fa45e3360ee5/ monetary_policy_report_3_14. pdf? $v=03 / 09 / 2017123530 \& f t=. p d f$

21. Otambo, T. D. (2016). The effect of macro-economic variables on financial performance of commercial banking sector in Kenya (Master's Thesis). Retrieved from http:// erepository.uonbi.ac.ke/bitstream/ handle/11295/99651/Otambo The $\% 20$ Effect $\% 20$ Of\%20MacroEconomic\%20Variables\%20On\%20 Financial\%20Performance $\% 20$ Of\%20Commercial\%20Bank-
ing\%20Sector\%20In\%20Kenya. pdf?sequence $=1$

22. Phiri, P. (2017). Changes in Inflation Persistence Prior and Subsequent to the subprime crisis: What are the Implications for South Africa? Journal of Reviews on Global Economics, 6, 198-207. https://doi. org/10.6000/1929-7092.2017.06.18

23. Pierdzioch, C., Reid, M. B. \& Gupta, R. (2014). Forecasting the South African inflation rate: On asymmetric loss and forecast rationality (Stellenbosch Economic Working Papers No. 26/14). Retrieved from https://ideas.repec. org/p/sza/wpaper/wpapers231.html

24. Rapu, S., Gaiya, B., Eboreime, M., Nkang, M., Audu, N., Golit, P., \& Okafor, H. (2016). A quantitative exploration of the drivers of inflation in Nigeria. Economic and Financial Review, 54(2), 1-21. Retrieved from https://www.cbn. gov.ng/Out/2018/RSD/CBN\%20 EFR\%20Volume\%2054\%20No\%20 2\%20June\%202016\%20-\%20 Draft\%20for\%20Upload.pdf

25. Sekaran, U., \& Bougie, R. J. (2016) Research methods for business: A Skill building approach (7th ed.) John Wiley \& Sons.

26. South African Reserve Bank. (2019). Monetary policy review April 2019. Retrieved from https://www.resbank.co.za/Lists/News\%20and\%20 Publications/Attachments/9206/ Monetary\%20Policy\%20Review\%20 \%E2\%80\%93\%20April\%202019.pdf

27. Tawiah, V. K., Benjamin, M., \& Dorothee, M. (2015). Inflation Accounting: More questions than answers. International Journal of Management and Business, 5(3), 150-164. https://doi.org/10.2139/ ssrn. 2592883

28. Tekatel, W. L. (2019). Financial Performance Analysis: A study on Selected Private Banks in Ethiopia (Master's Thesis). https://doi. org/10.13140/RG.2.2.33643.39203

29. Wilson, J. (2014). Essentials of business research: A guide to doing your research project. Sage. Retrieved from https://www.academia. edu/39919079/Essentials_of_Business_Research_A_Guide_to_Doing_Your_Research_Project_Jonathan_Wilson 